\title{
Free and immobilized Lactobacillus casei ATCC 393 on whey protein as starter cultures for probiotic Feta-type cheese production
}

\author{
Dimitra Dimitrellou, ${ }^{*}$ Panagiotis Kandylis, $\dagger^{1}$ Marianthi Sidira, ${ }^{*}$ Athanasios A. Koutinas, $\dagger$ and Yiannis \\ Kourkoutas* \\ *Applied Microbiology and Molecular Biotechnology Research Group, Department of Molecular Biology \& Genetics, \\ Democritus University of Thrace, Alexandroupolis, 68100, Greece \\ †Food Biotechnology Group, Section of Analytical Environmental and Applied Chemistry, Department of Chemistry, \\ University of Patras, GR-26500 Patras, Greece
}

\begin{abstract}
The use of free and immobilized Lactobacillus casei ATCC 393 on whey protein as starter culture in probiotic Feta-type cheese production was evaluated. The probiotic cultures resulted in significantly higher acidity; lower $\mathrm{pH}$; reduced counts of coliforms, enterobacteria, and staphylococci; and improved quality characteristics compared with cheese with no culture. Microbiological and strain-specific multiplex PCR analysis showed that both free and immobilized L. casei ATCC 393 were detected in the novel products at levels required for conferring a probiotic effect at the end of the ripening. The effect of starter culture on production of volatile compounds was investigated by the solid-phase microextraction gas chromatography-mass spectrometry analysis technique. The immobilized cells resulted in an improved profile of aroma-related compounds and the overall high quality of the novel products was ascertained by the preliminary sensory test. Finally, the high added value produced by exploitation of whey, which is an extremely polluting industrial waste, was highlighted and assessed.
\end{abstract}

Key words: Lactobacillus casei, whey protein, cell immobilization, Feta-type cheese

\section{INTRODUCTION}

Currently, much interest exists in developing novel foods containing probiotic microorganisms, such as bifidobacteria and lactic acid bacteria (LAB). Such functional foods demonstrate great potential in promoting human health. Maintenance of the intestinal microbial homeostasis, prevention of pathogenic infections, stabilization of the gastrointestinal (GI) barrier function, reduction of blood cholesterol and production of anticarcinogenic and antimutagenic compounds

Received October 12, 2013.

Accepted February 12, 2014.

${ }^{1}$ Corresponding author: pkandylis@yahoo.gr
(Kailasapathy and Chin, 2000) are included among the beneficial effects of probiotic-based foods, mainly yogurt and other dairy products. To deliver the health benefits, probiotics need to contain an adequate amount of live bacteria (at least $10^{6} \mathrm{cfu} / \mathrm{g}$ ), able to survive the acidic conditions of the upper GI tract and proliferate in the intestine, a requirement that is not always fulfilled (Boylston et al., 2004).

Cheese is among the most available versatile food products offering opportunities for marketing strategies as a probiotic delivery vehicle. The high $\mathrm{pH}$ of cheese acts as a buffer against the high acidic environment in the stomach, whereas the relatively high fat content offers additional protection (Stanton et al., 1998). Therefore, increased survival rates of probiotic bacteria during storage and passage through the GI tract are expected.

It is well established that cell immobilization enhances the viability of cultures (Dimitrellou et al., 2008). Milk proteins are natural vehicles for probiotic cells and due to their structural and physicochemical properties they can be used as a delivery system (Livney, 2010). In a previous study, thermally dried immobilized kefir on casein was used as a starter culture in dried whey cheese production, resulting in extended shelf life and improved volatile and sensory profiles (Dimitrellou et al., 2009).

Among LAB, the Lactobacillus casei ATCC 393 strain has been extensively incorporated into food products to confer probiotic properties. Recently, the probiotic properties of free and immobilized L. casei ATCC 393 were assessed by documenting survival after transit through the GI tract, adhesion at the large intestine and regulation of the intestinal microbial flora in rats (Sidira et al., 2010). In addition, a new method was proposed for monitoring the survival of $L$. casei ATCC 393 in probiotic yogurts, with excellent results (Sidira et al., 2013).

Feta cheese, one of the most significant and popular dairy products in Greece, with its characteristic slightly acid, salty taste, pleasant organoleptic properties, and 
worldwide acceptance, is a soft, white cheese ripened in brine. Traditionally, Feta cheese was prepared from either thermized or raw ewe milk on small family-owned premises with elementary equipment by using only rennet and without the addition of any starter cultures. Its characteristic flavor and texture were developed by the action of the natural lactic acid microflora of milk. At present, most Feta cheese is produced from ewe milk or a mixture of ewe and goat milk in commercial cheese dairies, with yogurt culture for lactic acid production, followed by addition of rennet for completion of precipitation. The produced cheeses are consumed after a 2-mo ripening period. The maturation period is necessary for the sanitation of cheese products, especially those made from raw milk. Hence, the aim of the present study was to evaluate the use of free and immobilized L. casei ATCC 393 on whey protein for the production of Feta-type cheese.

\section{MATERIALS AND METHODS}

\section{Probiotic Strain}

Lactobacillus casei ATCC 393 (DSMZ, Braunschweig, Germany) was grown at $37^{\circ} \mathrm{C}$ on de Man, Rogosa, and Sharpe (MRS) broth (Fluka, Buchs, Switzerland). The medium was sterilized at $130^{\circ} \mathrm{C}$ for 15 min before use.

\section{Immobilization of L. casei on Whey Protein}

For cell immobilization, $50 \mathrm{~mL}$ of whey (AVIGAL SA, Patras, Greece), containing $5 \mathrm{~g}$ (wet weight) of $L$. casei ATCC 393, was sprayed at whey cheese curd (500 g) during cloth filtration at $37^{\circ} \mathrm{C}$. The mixture was left for approximately $12 \mathrm{~h}$ at room temperature $\left(18-22^{\circ} \mathrm{C}\right)$ for completion of filtration. The whey protein was produced from sweet whey remaining after Feta-cheese production, according to the method applied for traditional Myzithra-type cheese manufacture (Dimitrellou et al., 2007).

\section{Cheesemaking}

Feta-type cheese with immobilized cells (sample FIC) was produced using pasteurized and standardized ovine milk (casein-to-fat ratio: 0.7, $\mathrm{pH} 6.69$, and lactose: 4.5\%; AVIGAL SA). Immobilized L. casei on whey protein $(50 \mathrm{~g} / \mathrm{L}$ of milk, resulting in approximately $10 \mathrm{log}$ $\mathrm{cfu} / \mathrm{L}$ of milk) was added to milk heated at $37^{\circ} \mathrm{C}$. After $30 \mathrm{~min}$, commercial rennet $(0.01 \%)$ was added and the mixture was left undisturbed for $2 \mathrm{~h}$ for curd formation. Subsequently, the curd was cut in squares (diameter $\approx 1 \mathrm{~cm}$ ), left undisturbed for $10 \mathrm{~min}$, and then cloth filtered overnight at room temperature $\left(18-22^{\circ} \mathrm{C}\right)$ for complete whey removal. Then, the cheese surface was salted $(2 \%$, wt $/ \mathrm{wt})$ and after $72 \mathrm{~h}$, cheese samples were placed in brine $(10 \%, \mathrm{wt} / \mathrm{vol})$ at 15 to $18^{\circ} \mathrm{C}$ for $15 \mathrm{~d}$ and then at 4 to $6^{\circ} \mathrm{C}$ for the remaining $55 \mathrm{~d}$.

For comparison, Feta-type cheese with free L. casei (sample FFC) was produced, by inoculating milk heated at $37^{\circ} \mathrm{C}$ with free L. casei $(3.2 \mathrm{~g} / \mathrm{L}$ of milk, resulting in approximately $10 \log \mathrm{cfu} / \mathrm{L}$ of milk). Then, the procedure above was followed. Similarly, cheese without L. casei ATCC 393 (sample F) was prepared without milk inoculation.

All treatments were carried out in triplicate and the mean values are presented. Duplicate samples from each treatment were collected at various intervals $(0,1$, $4,15,30,45$, and $70 \mathrm{~d})$ and were subjected to physicochemical and microbiological analysis.

\section{Physicochemical Analysis}

Cheese samples (20 g each) were macerated with warm water $\left(40^{\circ} \mathrm{C}\right)$ to produce a total volume of $210 \mathrm{~mL}$. Each sample was then filtered and the filtrate was used for lactic acid, ethanol, and residual sugar determination (AOAC International, 1995). Moisture content, ash content, and acidity (expressed as lactic acid) of cheese samples were determined according to AOAC International (1995). Total nitrogen in DM was determined using the Kjeldahl procedure. Residual sugar (lactose, glucose, and galactose) and ethanol were determined using HPLC and GC analysis, respectively, as described previously (Dimitrellou et al., 2009). All analyses were carried out in triplicate and the mean data are presented.

\section{Solid-Phase Microextraction GC-MS Analysis}

Cheese samples ripened for $70 \mathrm{~d}$ were used to study the volatile composition by solid-phase microextraction (SPME) GC-MS analysis. The procedure described in a previous study (Dimitrellou et al., 2009) was followed. Identification was carried out by comparing the retention times and mass spectra of volatiles to those of authentic compounds generated in the laboratory, by mass spectra obtained from NIST107, NIST21, and SZTERP libraries [CLASS 5000 software of GC-17A/QP5050A (GC-MS); Shimadzu Corp., Kyoto, Japan], and by determining Kovats retention indices and comparing them with those reported in the literature (Bianchi, et al., 2007; Dimitrellou et al., 2009; Kandylis et al., 2010). Each determination was carried out in triplicate and the mean data are presented.

\section{Microbiological Analyses}

Microbiological analysis was carried out as described previously (Dimitrellou et al., 2009). 


\section{Determination of L. casei ATCC 393 Levels}

To determine the levels of our strain in probiotic cheese samples, a methodology recently described by Sidira et al. (2010) was followed. Briefly, after enumeration of lactobacilli on MRS agar, the plates corresponding to all dilutions were washed with $10 \mathrm{~mL}$ of sterilized $1 / 4$ ringer solution and then the cell suspensions were subjected to molecular analysis based on multiplex PCR for detection of L. casei ATCC 393 (Karapetsas et al., 2010). Hence, genomic DNA from lactobacilli suspensions was extracted using a DNeasy Tissue Kit (Qiagen GmbH, Hilden, Germany) according to the manufacturer's protocol. Multiplex PCR reactions were carried out in a total volume of $50 \mu \mathrm{L}$, containing $5 \mathrm{U}$ of Taq DNA polymerase (HyTest Ltd., Turku, Finland), $400 \mu M$ concentration of each deoxyribonucleotide triphosphate (dNTP; Promega Corp., Madison, WI), $1.5 \mathrm{mM} \mathrm{MgCl}$ (HyTest Ltd.) and $100 \mathrm{ng}$ of template DNA. The set of specific for L. casei ATCC 393 primers used consisted of GGCGACCAAGGCAGCG (10 pmol), CTTCGGTTTCATCTTCC (50 pmol), and GGCCAACTTTTTCCATA (50 pmol). Additionally, a set of universal for lactobacilli primers were used as positive controls, which consisted of AGCAGTAGGGAATCTTCCA (10 pmol) and ATTYCACCGCTACACATG (10 pmol). Amplification was carried out in a thermal cycler (Mastercycler; Eppendorf AG, Hamburg, Germany) under the following conditions: $94^{\circ} \mathrm{C}(2 \mathrm{~min}) ; 25$ cycles of $94^{\circ} \mathrm{C}(15 \mathrm{~s}), 51^{\circ} \mathrm{C}(15 \mathrm{~s})$, and $72^{\circ} \mathrm{C}(30 \mathrm{~s})$; and a final extension step at $72^{\circ} \mathrm{C}(1$ $\mathrm{min}$ ). The PCR products were separated on $1.5 \%$ (wt/ vol) agarose gels, visualized under UV illumination, and photographed with a digital camera (Gel Doc EQ System; Bio-Rad Laboratories Inc., Hercules, CA).

\section{Preliminary Sensory Evaluation}

Samples of approximately $25 \mathrm{~g}$ of cheese ripened for $70 \mathrm{~d}$ were presented in random order in 5-cm Petri dishes served at room temperature. Sensory evaluation was conducted in duplicate by 14 laboratory members (7 experienced laboratory members and 7 untrained laboratory members) using locally approved protocols. The panel was asked to give scores on a 0 to 10 scale $(0=$ unacceptable; $10=$ exceptional) for attributes grouped into 2 categories: aroma (cheese-like odor, animal odor, fruity odor, and moist odor) and taste (milk taste, acid taste, rancid taste, sweet taste, salt taste, spicy taste, bitter taste, taste persistence, pungent flavor, mature flavor and burning sensation; Dimitrellou et al., 2007). The overall score was calculated as the average of the above 2 categories of attributes. Panelists used water to clean their palates between samples. Samples were coded using 3-dight numbers and presented to panelists.

\section{Experimental Design and Statistical Analysis}

All experiments were carried out in triplicate. Significance was established at $P<0.05$. Results were analyzed for statistical significance with ANOVA, and Duncan's multiple range test was used to determine significant differences among results; coefficients, ANOVA tables, and significance $(P<0.05)$ were computed using Statistica version 5.0 (StatSoft Inc., Tulsa, OK). Principal component analysis of data was computed using SPSS software (version 17.0; SPSS Inc., Chicago, IL).

\section{RESULTS AND DISCUSSION}

\section{Physicochemical Characteristics of Feta-Type Cheeses}

The physicochemical parameters of Feta-type cheeses produced with and without L. casei ATCC 393 culture are presented in Table 1.

All parameters ranged in levels usually observed in Feta-type cheese (Litopoulou-Tzanetaki et al., 1993). Both L. casei and the ripening time significantly affected $(P<0.05)$ all parameters studied except ethanol and ash content. Ethanol and ash content were only affected by the ripening time $(P<0.05)$. A strong interaction between the starter culture and the ripening time was also observed affecting sugars, $\mathrm{pH}$, and acidity $(P<0.05)$. The use of immobilized $L$. casei resulted in higher lactic acid concentrations and a lower $\mathrm{pH}$ during filtration compared with free $L$. casei and ranged in levels that are essential for the draining of Feta cheese. Lactic acid content was significantly $(P<0.05)$ higher, whereas the $\mathrm{pH}$ and sugar content were significantly $(P<0.05)$ lower in cheese samples produced with free (FFC samples) or immobilized L. casei on whey protein (FIC samples) compared with cheese with no starter culture ( $\mathrm{F}$ samples). As a consequence, the final $\mathrm{pH}$ in $\mathrm{F}$ samples was significantly higher $(P<0.05)$ compared with the probiotic samples. The increase in $\mathrm{pH}$ values and the decrease in acidity at the late stages of ripening could be attributed to the formation of basic nitrogenous compounds that acted as buffering agents and to the possible diffusion of organic acids to brine. The lower $\mathrm{pH}$ values of the probiotic cheeses resulted in faster whey removal, whereas brine led to a significant increase in moisture content, which is a usual observation for cheeses (Litopoulou-Tzanetaki et al., 1993). Moisture content was significantly $(P<0.05)$ affected by both the addition of $L$. casei starter culture and the ripening process. During ripening, it was reduced and 


\begin{tabular}{|c|c|c|c|c|c|c|c|c|c|c|c|}
\hline Cheese $^{1}$ & $\begin{array}{l}\text { Ripening } \\
\text { period (d) }\end{array}$ & $\begin{array}{l}\text { Lactose } \\
\text { (g/100 g of } \\
\text { cheese) }\end{array}$ & $\begin{array}{l}\text { Glucose } \\
\text { (g/100 g of } \\
\text { cheese) }\end{array}$ & $\begin{array}{l}\text { Galactose } \\
\text { (g/100 } \mathrm{g} \text { of } \\
\text { cheese) }\end{array}$ & $\begin{array}{l}\text { Ethanol } \\
\text { (g/100 g of } \\
\text { cheese) }\end{array}$ & $\mathrm{pH}$ & $\begin{array}{c}\text { Acidity } \\
\text { ( } \mathrm{g} \text { of lactic } \\
\text { acid/100 } \\
\mathrm{g} \text { of cheese) }\end{array}$ & $\begin{array}{l}\text { Moisture } \\
(\%, w t / w t)\end{array}$ & $\begin{array}{c}\text { Ash } \\
(\%, \mathrm{wt} / \mathrm{wt})\end{array}$ & $\begin{array}{l}\text { Total } N \text { in } \\
\text { DM (\%) }\end{array}$ & $\begin{array}{l}\text { Preliminary } \\
\text { sensory } \\
\text { evaluation }\end{array}$ \\
\hline \multirow[t]{7}{*}{$\mathrm{F}$} & 0 & $3.45 \pm 0.15^{\mathrm{a}}$ & $0.13 \pm 0.03^{\mathrm{c}}$ & $0.28 \pm 0.04^{\mathrm{ab}}$ & $0.02 \pm 0.01^{\mathrm{fg}}$ & $6.58 \pm 0.15^{\mathrm{a}}$ & $0.11 \pm 0.01^{\mathrm{g}}$ & $61.2 \pm 2.3^{\mathrm{a}}$ & $1.45 \pm 0.10^{\mathrm{c}}$ & & \\
\hline & 1 & $3.37 \pm 0.13^{\mathrm{a}}$ & $\operatorname{Tr}^{3}$ & $0.19 \pm 0.03^{\mathrm{c}}$ & $0.01 \pm 0.01^{\mathrm{g}}$ & $6.55 \pm 0.13^{\mathrm{a}}$ & $0.11 \pm 0.01^{\mathrm{g}}$ & $54.6 \pm 1.9^{\text {bcde }}$ & $2.09 \pm 0.13^{\mathrm{c}}$ & & \\
\hline & 4 & $3.15 \pm 0.12^{\mathrm{b}}$ & $\operatorname{Tr}$ & $\operatorname{Tr}$ & $0.09 \pm 0.02^{\text {bcde }}$ & $6.48 \pm 0.09^{\mathrm{a}}$ & $0.14 \pm 0.02^{\mathrm{g}}$ & $48.4 \pm 1.4^{\mathrm{ef}}$ & $5.11 \pm 0.23^{\mathrm{b}}$ & & \\
\hline & 15 & $1.90 \pm 0.09^{\mathrm{c}}$ & $\operatorname{Tr}$ & $\operatorname{Tr}$ & $0.18 \pm 0.03^{\mathrm{a}}$ & $5.88 \pm 0.11^{\mathrm{bc}}$ & $0.47 \pm 0.05^{\mathrm{ef}}$ & $58.0 \pm 2.2^{\mathrm{abc}}$ & $5.87 \pm 0.28^{\mathrm{ab}}$ & & \\
\hline & 30 & $1.54 \pm 0.07^{\mathrm{e}}$ & $\operatorname{Tr}$ & $\operatorname{Tr}$ & $0.19 \pm 0.03^{\mathrm{a}}$ & $5.79 \pm 0.09^{\mathrm{bc}}$ & $0.40 \pm 0.05^{\mathrm{ef}}$ & $57.5 \pm 2.1^{\mathrm{abcd}}$ & $6.09 \pm 0.30^{\mathrm{a}}$ & & \\
\hline & 45 & $1.10 \pm 0.06^{\text {ghi }}$ & $\mathrm{Tr}$ & $\operatorname{Tr}$ & $0.09 \pm 0.02^{\text {bcde }}$ & $5.62 \pm 0.08^{\mathrm{cd}}$ & $0.29 \pm 0.03^{\mathrm{fg}}$ & $57.9 \pm 2.1^{\mathrm{abc}}$ & $6.11 \pm 0.29^{\mathrm{a}}$ & & \\
\hline & 70 & $0.94 \pm 0.06^{\mathrm{hij}}$ & $\operatorname{Tr}$ & $\operatorname{Tr}$ & $0.06 \pm 0.02^{\text {cdefg }}$ & $5.61 \pm 0.09^{\mathrm{cd}}$ & $0.29 \pm 0.04^{\mathrm{fg}}$ & $58.1 \pm 2.2^{\mathrm{abc}}$ & $6.13 \pm 0.30^{\mathrm{a}}$ & $5.83 \pm 0.09^{\mathrm{a}}$ & $6.95 \pm 0.07^{\mathrm{b}}$ \\
\hline \multirow[t]{7}{*}{ FFC } & 0 & $1.57 \pm 0.07^{\mathrm{e}}$ & $0.29 \pm 0.04^{\mathrm{a}}$ & $0.31 \pm 0.04^{\mathrm{a}}$ & $0.02 \pm 0.01^{\mathrm{fg}}$ & $6.09 \pm 0.13^{\mathrm{b}}$ & $0.18 \pm 0.03^{\mathrm{g}}$ & $60.1 \pm 2.3^{\mathrm{ab}}$ & $1.55 \pm 0.14^{\mathrm{c}}$ & & \\
\hline & 1 & $1.49 \pm 0.07^{\mathrm{e}}$ & $0.13 \pm 0.03^{\mathrm{c}}$ & $0.23 \pm 0.03^{\mathrm{bc}}$ & $0.02 \pm 0.01^{\mathrm{fg}}$ & $5.54 \pm 0.10^{\text {cd }}$ & $0.32 \pm 0.04^{\mathrm{fg}}$ & $51.7 \pm 1.6^{\text {cdef }}$ & $2.10 \pm 0.18^{\mathrm{c}}$ & & \\
\hline & 4 & $1.25 \pm 0.06^{\mathrm{fg}}$ & $0.06 \pm 0.02^{\mathrm{d}}$ & $0.10 \pm 0.02^{\mathrm{d}}$ & $0.04 \pm 0.01^{\text {defg }}$ & $5.01 \pm 0.12^{\mathrm{e}}$ & $0.54 \pm 0.06^{\mathrm{de}}$ & $46.9 \pm 1.3^{\mathrm{f}}$ & $5.12 \pm 0.23^{\mathrm{b}}$ & & \\
\hline & 15 & $1.16 \pm 0.06^{\mathrm{gh}}$ & $\operatorname{Tr}$ & $\operatorname{Tr}$ & $0.10 \pm 0.02^{\mathrm{bcd}}$ & $4.85 \pm 0.09^{\mathrm{ef}}$ & $0.72 \pm 0.07^{\mathrm{cd}}$ & $55.1 \pm 2.0^{\mathrm{abcd}}$ & $5.80 \pm 0.27^{\mathrm{ab}}$ & & \\
\hline & 30 & $0.88 \pm 0.05^{\mathrm{ij}}$ & $\operatorname{Tr}$ & $\operatorname{Tr}$ & $0.11 \pm 0.02^{\mathrm{bc}}$ & $4.80 \pm 0.10^{\mathrm{ef}}$ & $0.83 \pm 0.08^{\mathrm{abc}}$ & $54.9 \pm 2.0^{\mathrm{abcd}}$ & $5.99 \pm 0.29^{\mathrm{a}}$ & & \\
\hline & 45 & $0.41 \pm 0.04^{\mathrm{k}}$ & $\operatorname{Tr}$ & $\operatorname{Tr}$ & $0.07 \pm 0.02^{\text {cdefg }}$ & $4.78 \pm 0.11^{\mathrm{ef}}$ & $0.83 \pm 0.09^{\mathrm{abc}}$ & $55.1 \pm 2.0^{\mathrm{abcd}}$ & $6.09 \pm 0.30^{\mathrm{a}}$ & & \\
\hline & 70 & $\operatorname{Tr}$ & $\operatorname{Tr}$ & $\operatorname{Tr}$ & $0.08 \pm 0.02^{\text {bcdef }}$ & $4.79 \pm 0.09^{\mathrm{ef}}$ & $0.83 \pm 0.08^{\mathrm{bc}}$ & $55.8 \pm 2.1^{\mathrm{abcd}}$ & $6.05 \pm 0.30^{\mathrm{a}}$ & $5.85 \pm 0.09^{\mathrm{a}}$ & $7.50 \pm 0.06^{\mathrm{a}}$ \\
\hline \multirow[t]{7}{*}{ FIC } & 0 & $1.82 \pm 0.08^{\mathrm{c}}$ & $0.20 \pm 0.03^{\mathrm{b}}$ & $0.19 \pm 0.03^{\mathrm{c}}$ & $0.01 \pm 0.01^{\mathrm{g}}$ & $5.82 \pm 0.12^{\mathrm{bc}}$ & $0.29 \pm 0.04^{\mathrm{fg}}$ & $60.0 \pm 2.3^{\mathrm{ab}}$ & $1.65 \pm 0.17^{\mathrm{c}}$ & & \\
\hline & 1 & $1.40 \pm 0.07^{\mathrm{ef}}$ & $0.11 \pm 0.02^{\mathrm{c}}$ & $0.04 \pm 0.01^{\mathrm{e}}$ & $0.03 \pm 0.01^{\mathrm{efg}}$ & $5.34 \pm 0.09^{\mathrm{d}}$ & $0.68 \pm 0.07^{\mathrm{cd}}$ & $51.0 \pm 1.5^{\mathrm{def}}$ & $2.07 \pm 0.19^{\mathrm{c}}$ & & \\
\hline & 4 & $0.74 \pm 0.05^{\mathrm{j}}$ & $\operatorname{Tr}$ & $\operatorname{Tr}$ & $0.03 \pm 0.01^{\mathrm{efg}}$ & $4.95 \pm 0.10^{\mathrm{ef}}$ & $0.83 \pm 0.08^{\mathrm{bc}}$ & $46.2 \pm 1.3^{\mathrm{f}}$ & $5.07 \pm 0.23^{\mathrm{b}}$ & & \\
\hline & 15 & $0.33 \pm 0.04^{\mathrm{k}}$ & $\operatorname{Tr}$ & $\operatorname{Tr}$ & $0.11 \pm 0.02^{\mathrm{bc}}$ & $4.72 \pm 0.10^{\mathrm{ef}}$ & $0.97 \pm 0.08^{\mathrm{ab}}$ & $53.3 \pm 1.8^{\text {cdef }}$ & $5.69 \pm 0.25^{\mathrm{ab}}$ & & \\
\hline & 30 & $0.28 \pm 0.04^{\mathrm{k}}$ & $\operatorname{Tr}$ & $\operatorname{Tr}$ & $0.14 \pm 0.03^{\mathrm{ab}}$ & $4.65 \pm 0.11^{\mathrm{f}}$ & $1.04 \pm 0.10^{\mathrm{a}}$ & $54.3 \pm 1.9^{\text {bcde }}$ & $5.83 \pm 0.28^{\mathrm{ab}}$ & & \\
\hline & 45 & $\operatorname{Tr}$ & $\operatorname{Tr}$ & $\operatorname{Tr}$ & $0.08 \pm 0.02^{\text {bcdef }}$ & $4.70 \pm 0.09^{\mathrm{ef}}$ & $0.97 \pm 0.09^{\mathrm{ab}}$ & $54.5 \pm 1.9^{\text {bcde }}$ & $5.80 \pm 0.27^{\mathrm{ab}}$ & & \\
\hline & 70 & $\operatorname{Tr}$ & $\operatorname{Tr}$ & $\operatorname{Tr}$ & $0.04 \pm 0.01^{\text {defg }}$ & $4.69 \pm 0.07^{\mathrm{ef}}$ & $0.86 \pm 0.08^{\mathrm{abc}}$ & $54.8 \pm 1.5^{\text {abcde }}$ & $5.79 \pm 0.29^{\mathrm{ab}}$ & $6.25 \pm 0.10^{\mathrm{a}}$ & $7.65 \pm 0.07^{\mathrm{a}}$ \\
\hline
\end{tabular}

${ }^{\mathrm{a}-\mathrm{k}}$ Means within a column with different superscript letters differ $(P<0.05)$.

$\mathrm{F}=$ Feta-type cheese with no starter culture; FFC = Feta-type cheese produced by free $L$. case $i$ FIC $=$ Feta-type cheese produced by immobilized $L$. case $i$ on whey protein

${ }^{2}$ Scores were on a 0 to 10 scale $(0=$ unacceptable; $10=$ exceptional $)$.

${ }^{3} \mathrm{Tr}=$ traces. 
an increase was observed after $4 \mathrm{~d}$, due to the addition of brine. The ash content increased continuously during ripening in all cases. Immobilization did not affect the ash content $(P>0.05)$ of the produced cheeses. Cheeses with lower $\mathrm{pH}$ values (FFC and FIC) also presented lower ash content values. This may be attributed to the fact that low $\mathrm{pH}$ leads to whey removal and subsequently to high calcium phosphate loss from casein micelles (Lawrence et al., 1987). Total nitrogen in DM, determined after $70 \mathrm{~d}$, was significantly $(P<$ $0.05)$ higher in cheese samples produced with immobilized L. casei starter culture.

\section{Microbiological Analysis of Feta-Type Cheeses}

The association of the microbial groups examined during ripening of the probiotic Feta-type cheese samples is presented in Table 2 .

Both $L$. casei starter culture and the ripening time significantly affected $(P<0.05)$ all microbial groups analyzed in the present study. Significantly $(P<0.05)$ higher numbers of lactobacilli were detected in FFC and FIC cheeses and a significant reduction $(P<0.05)$ in their numbers after d 30 of ripening was reported in all cases. Numbers of coliforms, staphylococci, and enterobacteria were significantly $(P<0.05)$ reduced in Feta-type cheeses produced with $L$. casei culture (FFC and FIC samples) compared with cheeses with no starter culture (F samples). Yeasts were detected in similar numbers at all cheeses at the first days of ripening. However, their numbers were significantly $(P$ $<0.05)$ reduced in FFC and in FIC samples.

The relatively high numbers of microbial counts at the first day of ripening may have their origin from cheesemaking equipment, environment, and the sanitation conditions during cheese preparation (Viljoen, 2001), as cell enumeration of pasteurized standardized milk used for cheesemaking ranged in undetectable levels (data not shown). The observed reduction in the numbers of lactobacilli after d 30 of ripening was probably due to the development of conditions that do not favor their growth, such as low $\mathrm{pH}$, high salt content, lack of fermentative sugars, and possible production of bacteriocins (Fox et al., 1996). Similarly, the reduction in the numbers of lactococci after d 15 of ripening could be attributed to their sensitivity to high salt content. The detection of significant numbers of lactococci and lactobacilli even at cheese samples with no starter culture was probably due to the growth of nonstarter LAB that survived after pasteurization or located in the cheesemaking equipment (Fitzsimons et al., 1999). Nonstarter LAB continuously grow during ripening, even at levels of approximately $9 \mathrm{log} \mathrm{cfu} / \mathrm{g}$, despite their low initial numbers.
The drastic decrease in enterobacteria, coliform, and enterobacteria numbers in probiotic samples, due to $L$. casei activity, is in accordance with previous studies reporting depression of spoilage and pathogenic bacteria by probiotic cultures (Madureira et al., 2011). Yeasts and molds are not usually part of the starter cultures used in cheesemaking. However, relatively high numbers are detected in many soft, semi-hard and surfaceripened cheeses, having their origin from cheesemaking equipment and the environment and brine (Viljoen, 2001). The presence of yeasts is related to the consumption of lactic acid and the ethanol production, whereas their contribution in cheese ripening is attributed to their lipolytic and proteolytic action. Although yeasts were present in all samples in our study, their numbers decreased rapidly in FIC and FFC cheeses, probably due to the development of conditions that do not favor their growth by the action of $L$. casei culture.

The decrease in the numbers of yeasts and other microorganisms during ripening, especially in FIC and FFC, may be attributed to the combined effect of low $\mathrm{pH}$ value, depletion of sugars and increase in $L$. casei cell numbers. Several studies have reported the inhibitory effect of $L$. casei against other microorganisms, including yeasts and fungi (Beresford et al., 2001; Schnürer and Magnusson, 2005; Dalié et al., 2010).This trend is probably mediated by an inhibiting substance produced by $L$. casei, such as a bacteriocin, but also through competition for limiting metabolites (Beresford et al., 2001; Huttunen et al., 1995). Of note, Salmonella spp. and Staphylococcus aureus were not detected in any cheese sample during the whole ripening period.

\section{Determination of L. casei ATCC 393 Levels}

In probiotic food products, bacterial viability may be reduced due to the high content of salt and the low water activity and $\mathrm{pH}$. The results from multiplex PCR assay showed that $L$. casei ATCC 393 was detected in both FFC and FIC samples at levels required for conferring a probiotic effect (at least $6 \log \mathrm{cfu} / \mathrm{g}$; Figure 1). As expected, L. casei ATCC 393 was not detected in F samples. Similar results reporting survival of probiotic cultures in dairy products were previously published (Oberg et al., 2011). However, in those studies, determination of the levels of the adjunct cultures was based on assays unable to identify the probiotic among other LAB strains due to the lack of an accurate, reliable, convenient, and sensitive detection method. Therefore, the probiotic characterization of the products was dubious. To the best of our knowledge, this is the first report concerning detection and identification of the adjunct probiotic strain at the essential concentration for conferring a probiotic effect in cheese using an ef- 
Table 2. Effect of free and immobilized Lactobacillus casei on whey protein starter cultures on major microbial groups of Feta-type cheese

\begin{tabular}{|c|c|c|c|c|c|c|c|c|c|c|}
\hline Cheese $^{1}$ & $\begin{array}{l}\text { Ripening } \\
\text { period (d) }\end{array}$ & $\begin{array}{c}\text { Total aerobic } \\
\text { count }(\log \mathrm{cfu} / \mathrm{g})\end{array}$ & $\begin{array}{c}\text { Psychrophilic } \\
\text { bacteria } \\
(\log \text { cfu/g) }\end{array}$ & $\begin{array}{l}\text { Mesophilic } \\
\text { lactococci } \\
(\log \mathrm{cfu} / \mathrm{g})\end{array}$ & $\begin{array}{l}\text { Thermophilic } \\
\text { lactococci } \\
(\log \mathrm{cfu} / \mathrm{g})\end{array}$ & $\begin{array}{l}\text { Lactobacilli } \\
(\log \mathrm{cfu} / \mathrm{g})\end{array}$ & $\begin{array}{c}\text { Yeasts } \\
(\log \mathrm{cfu} / \mathrm{g})\end{array}$ & $\begin{array}{l}\text { Coliforms } \\
(\log \mathrm{cfu} / \mathrm{g})\end{array}$ & $\begin{array}{l}\text { Enterobacteria } \\
\quad(\log \mathrm{cfu} / \mathrm{g})\end{array}$ & $\begin{array}{l}\text { Staphylococci } \\
(\log \mathrm{cfu} / \mathrm{g})\end{array}$ \\
\hline \multirow[t]{7}{*}{$\mathrm{F}$} & 0 & $6.20 \pm 0.32^{\mathrm{h}}$ & $4.76 \pm 0.21^{\mathrm{h}}$ & $5.39 \pm 0.24^{\mathrm{f}}$ & $4.65 \pm 0.21^{\mathrm{i}}$ & $5.38 \pm 0.24^{\mathrm{g}}$ & $5.10 \pm 0.21^{\mathrm{fg}}$ & $5.05 \pm 0.21^{\text {bcde }}$ & $5.15 \pm 0.22^{\text {bcde }}$ & $4.39 \pm 0.20^{\operatorname{defg}}$ \\
\hline & 1 & $6.71 \pm 0.35^{\mathrm{gh}}$ & $5.66 \pm 0.28^{\text {gh }}$ & $6.50 \pm 0.35^{\mathrm{def}}$ & $4.80 \pm 0.21^{\mathrm{i}}$ & $6.68 \pm 0.35^{\mathrm{f}}$ & $6.29 \pm 0.32^{\mathrm{abc}}$ & $5.40 \pm 0.24^{\mathrm{bcd}}$ & $5.56 \pm 0.28^{\mathrm{bc}}$ & $5.45 \pm 0.24^{\mathrm{ab}}$ \\
\hline & 4 & $8.15 \pm 0.42^{\text {bcdef }}$ & $5.85 \pm 0.29^{\mathrm{efgh}}$ & $6.85 \pm 0.35^{\text {cde }}$ & $6.10 \pm 0.31^{\mathrm{gh}}$ & $7.04 \pm 0.37^{\mathrm{ef}}$ & $6.85 \pm 0.35^{\mathrm{a}}$ & $5.85 \pm 0.29^{\mathrm{ab}}$ & $5.91 \pm 0.29^{\mathrm{abc}}$ & $5.80 \pm 0.29^{\mathrm{a}}$ \\
\hline & 15 & $9.26 \pm 0.47^{\mathrm{ab}}$ & $6.09 \pm 0.31^{\text {cdefg }}$ & $7.76 \pm 0.40^{\mathrm{abcd}}$ & $7.66 \pm 0.40^{\text {cdef }}$ & $8.15 \pm 0.42^{\text {bcde }}$ & $6.95 \pm 0.36^{\mathrm{a}}$ & $6.25 \pm 0.32^{\mathrm{a}}$ & $6.55 \pm 0.35^{\mathrm{a}}$ & $5.75 \pm 0.28^{\mathrm{a}}$ \\
\hline & 30 & $8.53 \pm 0.43^{\text {abcde }}$ & $6.13 \pm 0.31^{\text {cdefg }}$ & $7.84 \pm 0.41^{\mathrm{abc}}$ & $7.20 \pm 0.37^{\mathrm{defg}}$ & $8.45 \pm 0.41^{\text {abcde }}$ & $6.13 \pm 0.31^{\mathrm{abcd}}$ & $6.40 \pm 0.33^{\mathrm{a}}$ & $6.64 \pm 0.35^{\mathrm{a}}$ & $5.15 \pm 0.22^{\mathrm{abc}}$ \\
\hline & 45 & $8.12 \pm 0.42^{\text {bcdef }}$ & $6.01 \pm 0.30^{\operatorname{defg}}$ & $7.20 \pm 0.37^{\mathrm{bcd}}$ & $6.85 \pm 0.35^{\mathrm{efg}}$ & $7.68 \pm 0.40^{\text {cdef }}$ & $5.69 \pm 0.28^{\text {cdef }}$ & $5.85 \pm 0.29^{\mathrm{ab}}$ & $6.01 \pm 0.30^{\mathrm{ab}}$ & $4.95 \pm 0.21^{\mathrm{bcd}}$ \\
\hline & 70 & $7.79 \pm 0.40^{\text {cdefg }}$ & $5.80 \pm 0.29^{\mathrm{fgh}}$ & $6.50 \pm 0.35^{\mathrm{def}}$ & $6.13 \pm 0.31^{\mathrm{gh}}$ & $6.70 \pm 0.35^{\mathrm{f}}$ & $5.09 \pm 0.21^{\mathrm{fg}}$ & $5.25 \pm 0.22^{\mathrm{bcd}}$ & $5.68 \pm 0.28^{\mathrm{bc}}$ & $4.18 \pm 0.19^{\text {efgh }}$ \\
\hline \multirow[t]{7}{*}{ FFC } & 0 & $6.89 \pm 0.35^{\mathrm{fgh}}$ & $6.11 \pm 0.31^{\text {cdefg }}$ & $5.63 \pm 0.28^{\mathrm{ef}}$ & $5.25 \pm 0.22^{\mathrm{hi}}$ & $7.38 \pm 0.38^{\mathrm{def}}$ & $5.18 \pm 0.22^{\mathrm{efg}}$ & $4.90 \pm 0.21^{\text {cde }}$ & $5.10 \pm 0.21^{\text {cde }}$ & $4.18 \pm 0.19^{\text {efgh }}$ \\
\hline & 1 & $7.48 \pm 0.39^{\text {defgh }}$ & $6.99 \pm 0.36^{\text {abcde }}$ & $7.92 \pm 0.41^{\mathrm{abc}}$ & $6.60 \pm 0.34^{\mathrm{fg}}$ & $8.53 \pm 0.43^{\mathrm{abcd}}$ & $6.40 \pm 0.33^{\mathrm{abc}}$ & $5.12 \pm 0.22^{\text {bcde }}$ & $5.16 \pm 0.22^{\text {bcde }}$ & $4.85 \pm 0.21^{\text {bcde }}$ \\
\hline & 4 & $8.75 \pm 0.45^{\text {abcd }}$ & $7.14 \pm 0.37^{\text {abcd }}$ & $8.59 \pm 0.43^{\mathrm{a}}$ & $8.15 \pm 0.42^{\mathrm{abcd}}$ & $9.05 \pm 0.46^{\mathrm{ab}}$ & $6.65 \pm 0.35^{\mathrm{ab}}$ & $5.25 \pm 0.22^{\mathrm{bcd}}$ & $5.35 \pm 0.24^{\mathrm{bcd}}$ & $5.15 \pm 0.22^{\mathrm{abc}}$ \\
\hline & 15 & $9.38 \pm 0.48^{\mathrm{ab}}$ & $7.48 \pm 0.39^{\mathrm{ab}}$ & $8.70 \pm 0.45^{\mathrm{a}}$ & $8.30 \pm 0.42^{\mathrm{abcd}}$ & $9.28 \pm 0.47^{\mathrm{ab}}$ & $6.20 \pm 0.32^{\mathrm{abcd}}$ & $5.75 \pm 0.28^{\mathrm{ab}}$ & $5.69 \pm 0.28^{\mathrm{bc}}$ & $4.38 \pm 0.20^{\mathrm{defg}}$ \\
\hline & 30 & $8.65 \pm 0.44^{\mathrm{abcd}}$ & $7.58 \pm 0.39^{\mathrm{ab}}$ & $8.65 \pm 0.44^{\mathrm{a}}$ & $7.85 \pm 0.41^{\text {bcde }}$ & $9.09 \pm 0.46^{\mathrm{ab}}$ & $5.85 \pm 0.29^{\text {bcdef }}$ & $5.69 \pm 0.28^{\mathrm{abc}}$ & $5.55 \pm 0.28^{\mathrm{bc}}$ & $3.78 \pm 0.19^{\text {ghi }}$ \\
\hline & 45 & $8.31 \pm 0.42^{\text {bcdef }}$ & $7.15 \pm 0.37^{\mathrm{abcd}}$ & $8.59 \pm 0.43^{\mathrm{a}}$ & $7.73 \pm 0.41^{\text {cdef }}$ & $8.83 \pm 0.46^{\mathrm{abc}}$ & $5.15 \pm 0.22^{\mathrm{efg}}$ & $4.81 \pm 0.21^{\mathrm{de}}$ & $5.15 \pm 0.22^{\text {bcde }}$ & $3.65 \pm 0.19^{\mathrm{hij}}$ \\
\hline & 70 & $8.12 \pm 0.42^{\text {bcdefg }}$ & $6.95 \pm 0.36^{\text {abcdef }}$ & $8.30 \pm 0.42^{\mathrm{ab}}$ & $7.30 \pm 0.38^{\operatorname{defg}}$ & $8.25 \pm 0.42^{\text {abcde }}$ & $4.15 \pm 0.20^{\mathrm{h}}$ & $3.50 \pm 0.19^{\mathrm{f}}$ & $4.56 \pm 0.21^{\mathrm{de}}$ & $3.17 \pm 0.18^{\mathrm{ijk}}$ \\
\hline \multirow[t]{7}{*}{ FIC } & 0 & $7.10 \pm 0.37^{\mathrm{efgh}}$ & $6.40 \pm 0.33^{\text {bcdefg }}$ & $5.85 \pm 0.29^{\mathrm{ef}}$ & $5.30 \pm 0.22^{\mathrm{hi}}$ & $7.43 \pm 0.39^{\mathrm{def}}$ & $5.30 \pm 0.22^{\text {defg }}$ & $5.15 \pm 0.22^{\mathrm{bcd}}$ & $5.16 \pm 0.22^{\text {bcde }}$ & $4.10 \pm 0.19^{\mathrm{fgh}}$ \\
\hline & 1 & $8.70 \pm 0.45^{\text {abcd }}$ & $7.35 \pm 0.38^{\mathrm{ab}}$ & $7.95 \pm 0.41^{\mathrm{abc}}$ & $6.90 \pm 0.36^{\mathrm{efg}}$ & $8.95 \pm 0.46^{\mathrm{ab}}$ & $6.08 \pm 0.31^{\text {abcde }}$ & $5.20 \pm 0.22^{\mathrm{bcd}}$ & $5.26 \pm 0.22^{\text {bcde }}$ & $4.55 \pm 0.20^{\text {cdef }}$ \\
\hline & 4 & $9.18 \pm 0.46^{\mathrm{abc}}$ & $7.52 \pm 0.39^{\mathrm{ab}}$ & $8.90 \pm 0.46^{\mathrm{a}}$ & $8.95 \pm 0.46^{\mathrm{ab}}$ & $9.11 \pm 0.46^{\mathrm{ab}}$ & $6.18 \pm 0.32^{\mathrm{abcd}}$ & $5.30 \pm 0.24^{\mathrm{bcd}}$ & $5.32 \pm 0.22^{\mathrm{bcd}}$ & $4.80 \pm 0.21^{\text {bcde }}$ \\
\hline & 15 & $9.84 \pm 0.51^{\mathrm{a}}$ & $7.54 \pm 0.39^{\mathrm{ab}}$ & $9.00 \pm 0.46^{\mathrm{a}}$ & $9.08 \pm 0.46^{\mathrm{a}}$ & $9.70 \pm 0.49^{\mathrm{a}}$ & $6.18 \pm 0.32^{\mathrm{abcd}}$ & $5.60 \pm 0.28^{\mathrm{abcd}}$ & $5.69 \pm 0.28^{\mathrm{bc}}$ & $3.59 \pm 0.19^{\text {hijk }}$ \\
\hline & 30 & $8.86 \pm 0.46^{\mathrm{abcd}}$ & $7.48 \pm 0.39^{\mathrm{ab}}$ & $8.95 \pm 0.46^{\mathrm{a}}$ & $8.60 \pm 0.43^{\mathrm{abc}}$ & $9.43 \pm 0.48^{\mathrm{ab}}$ & $5.68 \pm 0.28^{\text {cdef }}$ & $5.18 \pm 0.22^{\mathrm{bcd}}$ & $5.08 \pm 0.21^{\text {cde }}$ & $3.09 \pm 0.18^{\mathrm{jkl}}$ \\
\hline & 45 & $8.56 \pm 0.43^{\mathrm{abcd}}$ & $7.70 \pm 0.40^{\mathrm{a}}$ & $8.90 \pm 0.46^{\mathrm{a}}$ & $8.00 \pm 0.42^{\mathrm{abcd}}$ & $9.05 \pm 0.46^{\mathrm{ab}}$ & $4.69 \pm 0.21^{\mathrm{gh}}$ & $4.33 \pm 0.20^{\mathrm{e}}$ & $4.45 \pm 0.20^{\mathrm{e}}$ & $2.95 \pm 0.18^{\mathrm{kl}}$ \\
\hline & 70 & $8.45 \pm 0.42^{\text {abcde }}$ & $7.23 \pm 0.37^{\mathrm{abc}}$ & $8.66 \pm 0.44^{\mathrm{a}}$ & $7.56 \pm 0.39^{\text {cdef }}$ & $8.71 \pm 0.45^{\mathrm{abcd}}$ & $3.26 \pm 0.20^{\mathrm{i}}$ & $3.08 \pm 0.18^{\mathrm{f}}$ & $3.15 \pm 0.18^{\mathrm{e}}$ & $2.46 \pm 0.18^{1}$ \\
\hline
\end{tabular}

${ }^{\mathrm{a}-\mathrm{l}}$ Means within a column with different superscript letters differ $(P<0.05)$.

${ }^{1} \mathrm{~F}=$ Feta-type cheese with no starter culture; FFC = Feta-type cheese produced by free $L$. casei; FIC = Feta-type cheese produced by immobilized $L$. casei on whey protein. 
ficient, accurate, reliable, convenient, and sensitive molecular tool.

\section{Aroma-Related Compounds}

The development of unique aromatic compounds remains an undeniable aim of the cheese industry. Esters, organic acids, alcohols, carbonyl, and flavor compounds are generally considered the most important compounds usually identified in cheeses by the SPME GC-MS technique (Kourkoutas et al., 2006; Dimitrellou et al., 2007). However, the flavor of cheese appears to depend not on particular key components, but rather on a critical balance or a weighted concentration ratio of all of the components present.

For the evaluation of the aromatic profile, Feta-type cheese samples were analyzed using the SPME GC-MS technique. Semiquantitative results of the volatile compounds are presented in Tables 3 and 4 . In total, 44 compounds were detected: 33 compounds in FIC cheese, 40 compounds in FFC cheese, and 34 compounds in $\mathrm{F}$ cheese. The most important classes of compounds identified were esters, organic acids, alcohols, carbonyl compounds and lactones.

From a quantitative point of view, the significantly $(P<0.05)$ highest content of total volatiles and organic acids was observed in FIC cheese (Table 4), followed by FFC cheese, and then by $\mathrm{F}$ cheese. On the other hand, free cells of L. casei ATCC 393 resulted in significantly $(P<0.05)$ increased concentrations of esters, alcohols, and carbonyl compounds. As far as lactones are concerned, the addition of starter culture in either free or immobilized form resulted in significantly $(P<0.05)$ higher amounts.

A great diversity of esters exists in cheeses. Due to their high volatility in room temperature, esters contribute significantly to the flavor of the majority of cheese types, even at low concentrations. Most esters detected in the samples analyzed in our study are characterized by fruity, floral notes (Gallois and Langlois, 1990). Ethyl butanoate, ethyl hexanoate, ethyl octanoate, ethyl decanoate, and ethyl dodecanoate identified in all cases are known for their fruity notes, such as pineapple, banana, melon, and apricot. Similarly, 2-phenylethyl acetate, providing floral and rose-like attributes (Molimard and Spinnler, 1996), was also detected in all samples. Apart from their fruity contribution, esters are also considered important compounds because of their ability to reduce the effect of compounds with unpleasant aroma, such as the short-chain FA and phenolic compounds (Curioni and Bosset, 2002).

Free FA may derive from milk fat lipolysis or from the breakdown of amino acids and are considered important flavor components of a variety of cheeses (Cas-

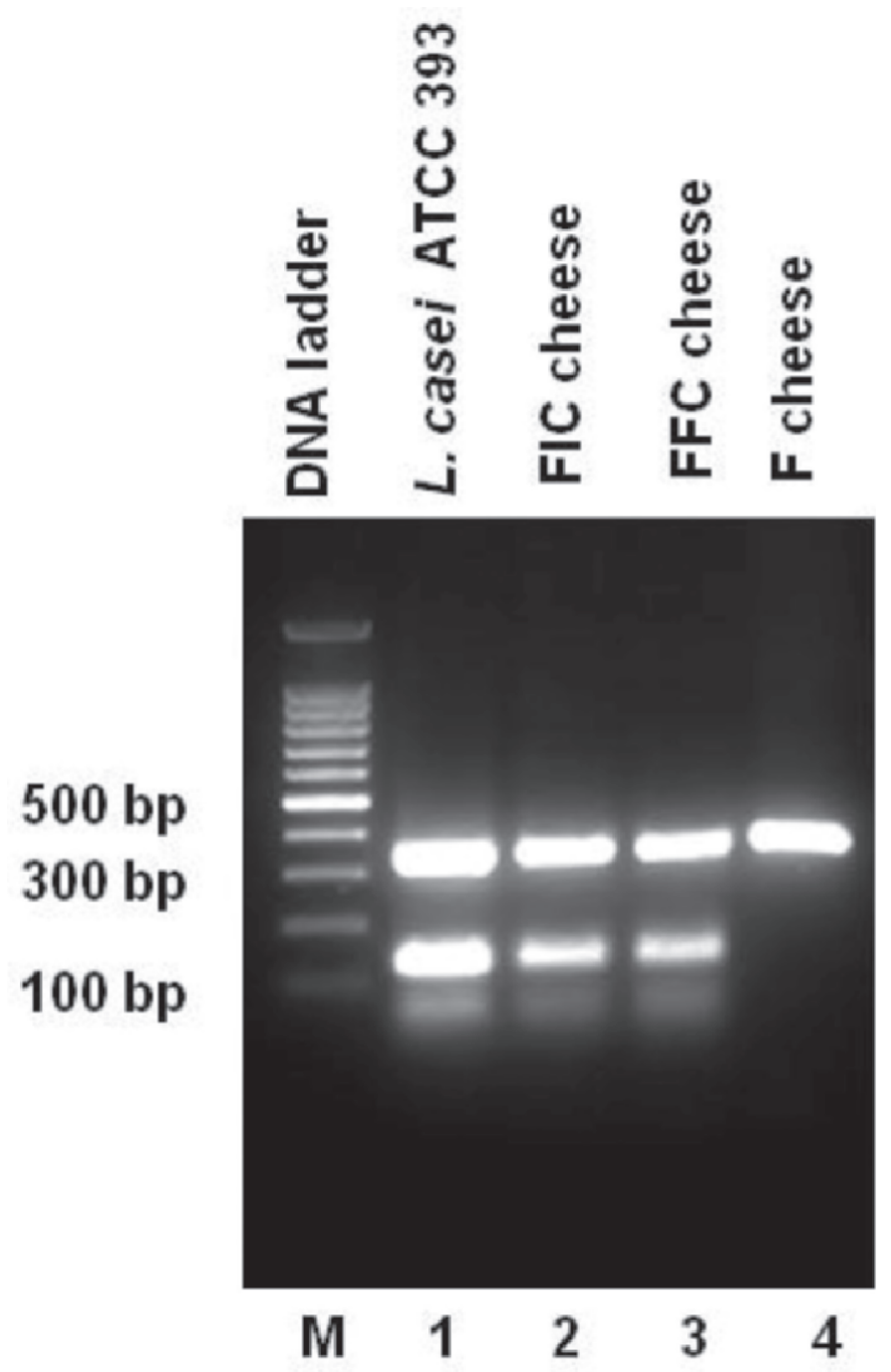

Figure 1. Molecular identification of Lactobacillus casei ATCC 393 at levels $\geq 6 \mathrm{log} \mathrm{cfu} / \mathrm{g}$ in probiotic cheese after $70 \mathrm{~d}$ of ripening, applying strain-specific multiplex PCR assay after lactobacilli enumeration with microbiological analysis. Lane $1=$ pure cultures of $L$. casei ATCC 393 served as a positive control; lane $2=$ Feta-type cheese produced by immobilized $L$. casei on whey protein (FIC sample); lane $3=$ Fetatype cheese produced by free $L$. casei (FFC sample); lane $4=$ Fetatype cheese with no starter culture (F sample).

tillo et al., 2007; Delgado et al., 2010; Delgado et al., 2011). In the present study, the acids with the higher concentrations were hexanoic acid, with a pungent, blue cheese flavor; octanoic acid known for its goaty, rancid, fruity flavor; and decanoic acid, which provides a rancid flavor. Dodecanoic acid, present in all cheeses, plays a minor role in cheese flavor due to its high perception threshold (Molimard and Spinnler, 1996).

Another important group of compounds in cheese aroma is alcohols. Ethanol, identified in all cheeses, having an alcohol, mild flavor note also present in fresh milk, may derive from lactose by the metabolic activ- 
Table 3. Effect of free and immobilized Lactobacillus casei on whey protein as starter culture on major aroma-related compounds ( $\mu \mathrm{g} / \mathrm{kg}$ of cheese) of Feta-type cheese after ripening for $70 \mathrm{~d}$ using the solid-phase microextraction (SPME) GC-MS technique

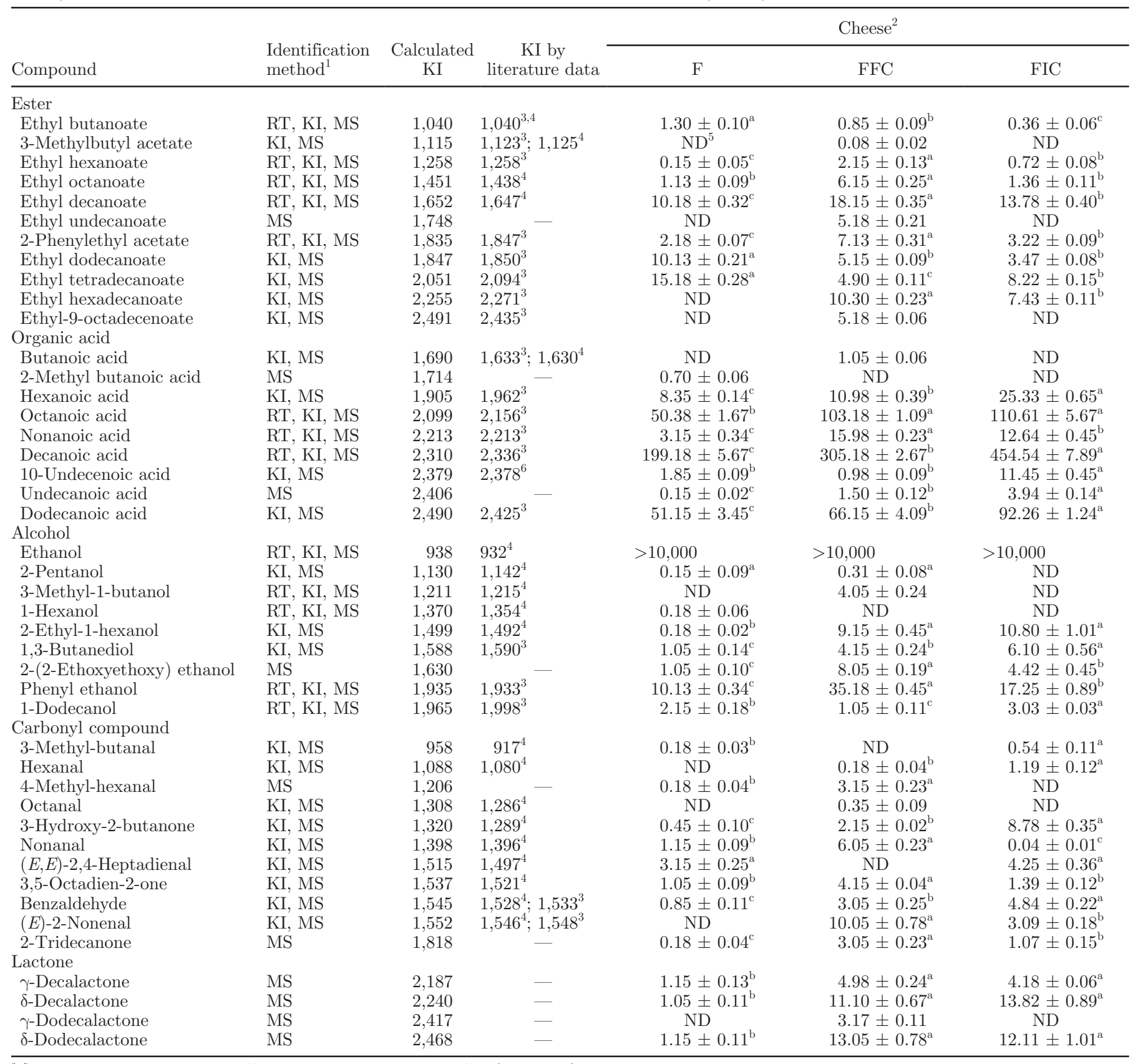

${ }^{\mathrm{a}-\mathrm{c}}$ Means within a row with different superscript letters differ $(P<0.05)$.

${ }^{1} \mathrm{RT}=$ positive identification by retention times that agree with authentic compounds and by mass spectra of authentic compounds generated in the laboratory; $\mathrm{KI}=$ tentative identification by the Kovats retention index; $\mathrm{MS}=$ tentative identification by mass spectra obtained from NIST107, NIST21, and SZTERP libraries [CLASS 5000 software of GC-17A/QP-5050A (GC-MS); Shimadzu Corp., Kyoto, Japan].

${ }^{2} \mathrm{~F}=$ Feta-type cheese with no starter culture; FFC = Feta-type cheese produced with free $L$. casei; FIC = Feta-type cheese produced with immobilized $L$. casei on whey protein.

${ }^{3}$ Kandylis et al. (2010).

${ }^{4}$ Bianchi et al. (2007).

${ }^{5} \mathrm{ND}=$ not detected.

${ }^{6}$ Dimitrellou et al. (2009). 
Table 4. Effect of free and immobilized Lactobacillus casei on whey protein as starter culture on major aroma groups $(\mu \mathrm{g} / \mathrm{kg}$ of cheese) of Feta-type cheese after ripening for $70 \mathrm{~d}$ using the solid-phase microextraction (SPME) GC-MS technique

\begin{tabular}{lrrr}
\hline & \multicolumn{3}{c}{ Cheese $^{1}$} \\
\cline { 2 - 4 } Compound & \multicolumn{1}{c}{ F } & \multicolumn{1}{c}{ FFC } & FIC \\
\hline Esters & $40.25 \pm 1.58^{\mathrm{b}}$ & $65.22 \pm 2.62^{\mathrm{a}}$ & $38.56 \pm 1.53^{\mathrm{b}}$ \\
Organic acids & $314.91 \pm 16.18^{\mathrm{c}}$ & $505.00 \pm 12.36^{\mathrm{b}}$ & $710.77 \pm 23.32^{\mathrm{a}}$ \\
Alcohols & $14.89 \pm 1.32^{\mathrm{c}}$ & $61.94 \pm 2.50^{\mathrm{a}}$ & $41.60 \pm 4.16^{\mathrm{b}}$ \\
Carbonyl compounds $_{\text {Lactones }}$ & $7.19 \pm 1.06^{\mathrm{b}}$ & $32.18 \pm 2.70^{\mathrm{a}}$ & $25.19 \pm 2.29^{\mathrm{a}}$ \\
Total & $3.35 \pm 0.49^{\mathrm{b}}$ & $32.30 \pm 2.55^{\mathrm{a}}$ & $30.11 \pm 2.77^{\mathrm{a}}$ \\
\hline
\end{tabular}

${ }^{\mathrm{a}-\mathrm{c}}$ Means within a row with different superscript letters differ $(P<0.05)$.

${ }^{1} \mathrm{~F}=$ Feta-type cheese with no starter culture; FFC $=$ Feta-type cheese produced with free $L$. casei; FIC = Feta-type cheese produced with immobilized $L$. casei on whey protein.

${ }^{2}$ Ethanol is excluded.

ity of starter cultures and yeasts (Fernández-García, 1996). Ethanol is an important flavor compound of many cheeses, such as Afuega'l Pitu (Fernández-García, 1996), Feta (Bintsis and Robinson, 2004; Kourkoutas et al., 2006), Roncal (Izco and Torre, 2000), and Myzithra cheese (Dimitrellou et al., 2007). 3-Mehtyl-1-butanol, detected in FFC samples, provides an alcoholic, floral note, whereas 1-hexanol, present in $\mathrm{F}$ cheese, is known for its fruity note (Gallois and Langlois, 1990). 2-Ethyl1-hexanol, identified in all cases, is considered as an important flavor compound and has been detected in high concentrations in many cheese types, such as Afuega'l Pitu (Fernández-García, 1996) and Myzithra cheese (Dimitrellou et al., 2007). One of the most odorous alcohols is phenyl ethanol, which was present in all cheese samples and was responsible for pleasant rose flower attributes (Molimard and Spinnler, 1996). Of note, the content of 2-ethyl-1-hexanol and phenyl ethanol was higher in FFC and FIC samples than in F samples.

The carbonyl compounds identified included mainly aldehydes and ketones and their concentrations were significantly higher in FFC and FIC samples than in $\mathrm{F}$ samples. 3-Methyl-butanal, present in F and FIC cheeses, can be derived from leucine and has a fruity aroma. Hexanal, detected in FFC and FIC samples; octanal, identified in FFC cheese; and nonanal, present in all cheeses, are described as having an aromatic note resembling fruits such as oranges (Molimard and Spinnler, 1996). Benzaldehyde detected in all cases is described as having an odor of bitter almond (Molimard and Spinnler, 1996). Acetoin (3-hydroxy-butanone), also identified in all samples, derives from reduction of diacetyl, which is mainly produced by the activity of LAB (Curioni and Bosset, 2002). Likewise, 2-tridecanone, which was present in all cheeses, is known for its fruity, green flavor note (Molimard and Spinnler, 1996).

Lactones are generally characterized by very pronounced fruity attributes, such as peach, apricot, and coconut. In general, $\delta$-lactones have a higher detec- tion threshold compared with $\gamma$-lactones (Molimard and Spinnler, 1996). However, the role of lactones in cheeses is not limited to their fruity aroma contribution, but they are considered important compounds due to their ability to suppress the unpleasant flavor of other components, such as FA, thus providing a milder and pleasant character. The concentration of lactones was almost 10-fold higher in FFC and FIC samples compared with $\mathrm{F}$ cheese, revealing the positive effect of L. casei on flavor formation.

Our results showed that a plethora of aroma compounds are formed by the action of free and immobilized L. casei ATCC 393. However, it is yet unknown and difficult to interpret the relationship between the microbial associations and the chemical compounds, due to the complexity of microbial interactions.

\section{Chemometrics}

Principal component analysis is used in exploratory analysis, as it gives graphical representations of intersample and intervariable relationships and provides a way to reduce the complexity of the data.

The application of the principal components analysis algorithm to data showed 3 distinctive samples (Figure 2 ), indicating that the volatile composition of the different cheese types was dependent on the nature of the starter culture.

\section{Preliminary Sensory Evaluation}

The cheese samples produced using free or immobilized L. casei starter culture were compared with Feta-type cheese produced with no starter culture in regard to their sensory characteristics. Feta-type cheeses produced with immobilized or free $L$. casei scored significantly $(P<0.05)$ higher values compared with cheese produced with no starter culture (Table 1). Both probiotic Feta-type cheese samples had a soft fine taste and an overall improvement in quality was evident. 


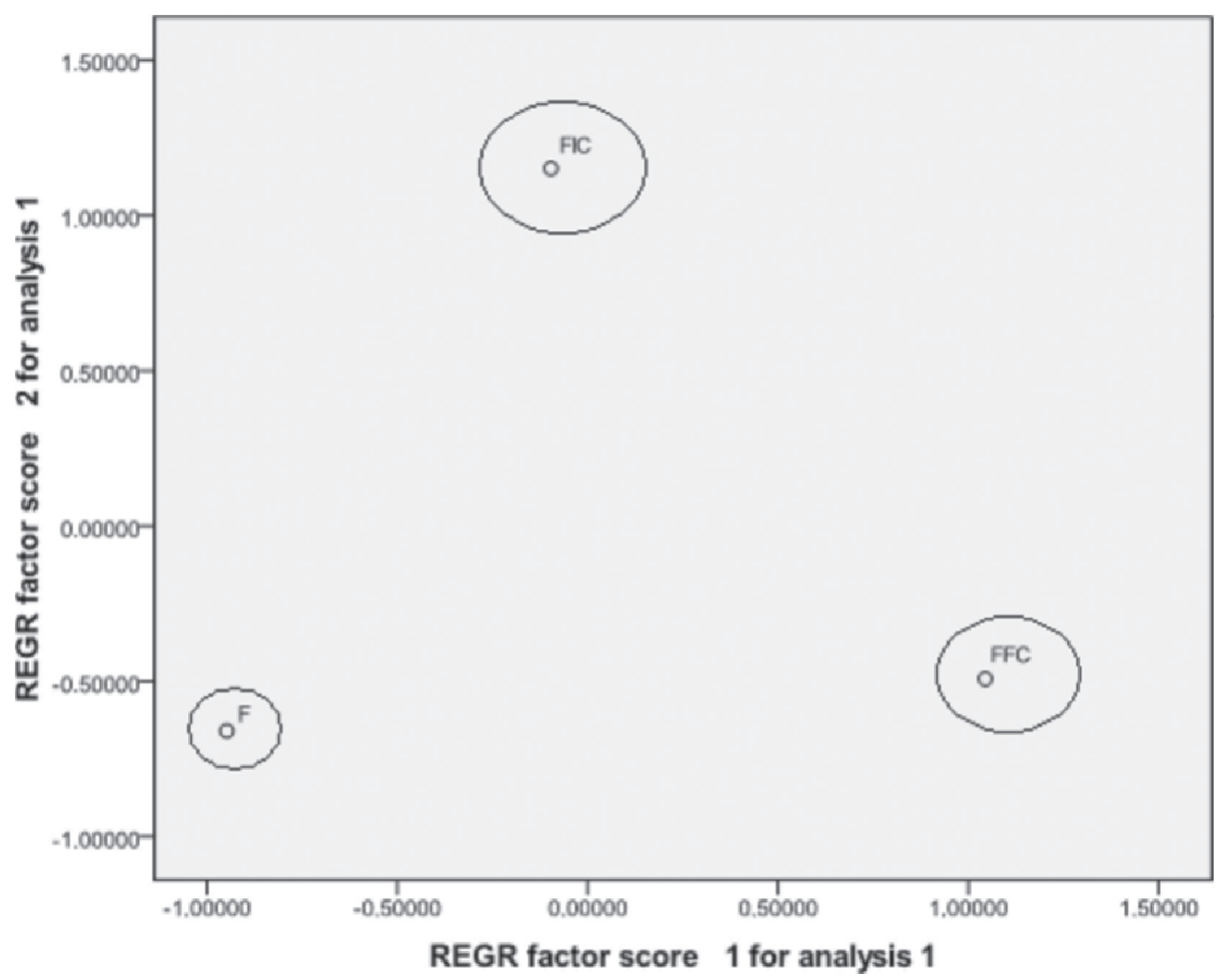

Figure 2. Principal component analysis plot of probiotic cheeses. F = Feta-type cheese with no starter culture; FFC $=$ Feta-type cheese produced with free Lactobacillus case $;$ FIC $=$ Feta-type cheese produced with immobilized $L$. casei on whey protein; REGR $=$ regression.

\section{Technological Considerations}

The use of whey protein for the immobilization of probiotic cultures is expected to create high added value in the food industry, leading to the development of an economically feasible, marketable, and environmentally friendly process in a series of food industrial applications by simultaneous exploitation of the high amounts of whey, which are difficult to dispose of or treat. Hence, the proposed technology may have a major impact on sustainable development. Additionally, as it has been proposed that milk proteins are natural vehicles for probiotic cells (Livney, 2010), functioning as buffering agents in vivo and protecting ingested bacterial strains at the upper GI tract (Charteris et al., 1998), immobilization of $L$. casei on whey protein is expected to improve cell survival during digestion.

\section{CONCLUSIONS}

The use of probiotics is already very common in dairy products; nevertheless, studies reporting the survival of adjunct probiotic strains in food products in adequate levels for conferring the health benefits are scarce in the literature, due to the lack of an accurate, reliable, convenient, and sensitive method of identification. Thus, the scope of the present study was to evaluate free and immobilized $L$. casei on whey protein as starter cultures in production of Feta-type cheese. The strategy adopted was, first, to maintain survival of the probiotic strain at suitable levels for conferring the health benefits at the time of consumption, second, to improve the quality characteristics of the new products, and, finally, to extend the products' shelf life by suppressing growth of spoilage and pathogenic bacteria. Our data clearly demonstrated that both free and immobilized $L$. casei on a whey protein matrix survived during the maturation process and were detected at the essential concentration for providing health benefits. The use of whey protein for the production of highly added-value products, such as probiotic foods, is expected to contribute significantly to the environmental problems associated with the disposal of this highly polluting waste.

\section{ACKNOWLEDGMENTS}

The research project was implemented within the framework of the Action "Supporting Postdoctoral 
Researchers" of the Operational Program "Education and Lifelong Learning" (Action's Beneficiary: General Secretariat for Research and Technology), and was cofinanced by the European Social Fund (ESF, Brussels, Belgium) and the Greek State.

\section{REFERENCES}

AOAC International. 1995. Official Methods of Analysis. 16th ed. AOAC International, Gaithersburg, MD.

Beresford, T. P., N. A. Fitzsimons, N. L. Brennan, and T. M. Cogan. 2001. Recent advances in cheese microbiology. Int. Dairy J. 11:259-274.

Bianchi, F., M. Careri, A. Mangia, and M. Musci. 2007. Retention indices in the analysis of food aroma volatile compounds in temperature-programmed gas chromatography: Database creation and evaluation of precision and robustness. J. Sep. Sci. 30:563-572.

Bintsis, T., and R. K. Robinson. 2004. A study of the effects of adjunct cultures on the aroma compounds of Feta-type cheese. Food Chem. 88:435-441.

Boylston, T. D., C. G. Vinderola, H. B. Ghoddusi, and J. A. Reinheimer. 2004. Incorporation of bifidobacteria into cheeses: Challenges and rewards. Int. Dairy J. 14:375-387.

Castillo, I., M. V. Calvo, L. Alonso, M. Juárez, and J. Fontecha. 2007. Changes in lipolysis and volatile fraction of a goat cheese manufactured employing a hygienized rennet paste and a defined strain starter. Food Chem. 100:590-598.

Charteris, W. P., P. M. Kelly, L. Morelli, and J. K. Collins. 1998. Development and application of an in vitro methodology to determine the transit tolerance of potentially probiotic Lactobacillus and Bifidobacterium species in the upper human gastrointestinal tract. J. Appl. Microbiol. 84:759-768.

Curioni, P. M. G., and J. O. Bosset. 2002. Review: Key odorants in various cheese types as determined by gas chromatography-olfactometry. Int. Dairy J. 12:959-984.

Dalié, D. K. D., A. M. Deschamps, and F. Richard-Forget. 2010. Lactic acid bacteria-Potential for control of mould growth and mycotoxins: A review. Food Contr. 21:370-380.

Delgado, F. J., J. González-Crespo, R. Cava, J. García-Parra, and R. Ramírez. 2010. Characterisation by SPME-GC-MS of the volatile profile of a Spanish soft cheese P.D.O. Torta del Casar during ripening. Food Chem. 118:182-189.

Delgado, F. J., J. González-Crespo, R. Cava, and R. Ramírez. 2011. Formation of the aroma of a raw goat milk cheese during maturation analysed by SPME-GC-MS . Food Chem. 129:1156-1163.

Dimitrellou, D., Y. Kourkoutas, I. M. Banat, R. Marchant, and A. A. Koutinas. 2007. Whey cheese production using freeze-dried kefir culture as a starter. J. Appl. Microbiol. 103:1170-1183.

Dimitrellou, D., Y. Kourkoutas, A. A. Koutinas, and M. Kanellaki. 2009. Thermally-dried immobilized kefir on casein as starter culture in dried whey cheese production. Food Microbiol. 26:809820 .

Dimitrellou, D., K. Tsaousi, Y. Kourkoutas, P. Panas, M. Kanellaki, and A. A. Koutinas. 2008. Fermentation efficiency of thermally dried immobilized kefir on casein as starter culture. Process Biochem. 43:1323-1329.

Fernández-García, E. 1996. Use of headspace sampling in the quantitative analysis of artisanal cheese aroma. J. Agric. Food Chem. 44:1839-1883.

Fitzsimons, N. A., T. M. Cogan, S. Condon, and T. Beresford. 1999. Phenotypic and genotypic characterization of non-starter lactic acid bacteria in mature Cheddar cheese. Appl. Environ. Microbiol. 65:3418-3426.

Fox, P. F., T. P. O'Connor, P. L. H. McSweeney, T. P. Guinee, and N. M. O'Brien. 1996. Cheese: Physical, biochemical and nutritional aspects. Adv. Food Nutr. Res. 39:163-328.

Gallois, A., and D. Langlois. 1990. New results in the volatile odorous compounds of French cheeses. Lait 70:89-106.

Huttunen, E., K. Noro, and Z. Yang. 1995. Purification and identification of antimicrobial substances produced by two Lactobacillus casei strains. Int. Dairy J. 5:503-513.

Izco, J. M., and P. Torre. 2000. Characterisation of volatile flavour compounds in Roncal cheese extracted by the 'purge and trap' method and analysed by GC-MS. Food Chem. 70:409-417.

Kailasapathy, K., and J. Chin. 2000. Survival and therapeutic potential of probiotic organisms with reference to Lactobacillus acidophilus and Bifidobacterium spp. Immunol. Cell Biol. 78:80-88.

Kandylis, P., C. Drouza, A. Bekatorou, and A. A. Koutinas. 2010. Scaleup of extremely low temperature fermentations of grape must by wheat supported yeast cells. Bioresour. Technol. 101:7484-7491.

Karapetsas, A., E. Vavoulidis, A. Galanis, R. Sandaltzopoulos, and Y. Kourkoutas. 2010. Rapid detection and identification of probiotic Lactobacillus casei ATCC 393 by multiplex PCR. J. Mol. Microbiol. Biotechnol. 18:156-161.

Kourkoutas, Y., P. Kandylis, P. Panas, J. S. G. Dooley, P. Nigam, and A. A. Koutinas. 2006. Evaluation of freeze-dried kefir coculture as starter in Feta-type cheese production. Appl. Environ. Microbiol. 72:6124-6135.

Lawrence, R. C., L. K. Creamer, and J. Gilles. 1987. Texture development during cheese ripening. J. Dairy Sci. 70:1748-1760.

Litopoulou-Tzanetaki, E., N. Tzanetakis, and A. Vafopoulou-Mastrojiannaki. 1993. Effect of the type of lactic starter on microbiological, chemical and sensory characteristics of Feta cheese. Food Microbiol. 10:31-41.

Livney, Y. D. 2010. Milk proteins as vehicles for bioactives. Curr. Opin. Colloid Interface Sci. 15:73-83.

Madureira, A. R., M. E. Pintado, A. M. P. Gomes, and F. X. Malcata. 2011. Incorporation of probiotic bacteria in whey cheese: Decreasing the risk of microbial contamination. J. Food Prot. 74:1194-1199.

Molimard, P., and H. E. Spinnler. 1996. Review: Compounds involved in the flavor of surface mold-ripened cheeses: Origins and properties. J. Dairy Sci. 79:169-184.

Oberg, C. J., L. V. Moyes, M. J. Domek, C. Brothersen, and D. J. McMahon. 2011. Survival of probiotic adjunct cultures in cheese and challenges in their enumeration using selective media. J. Dairy Sci. 94:2220-2230.

Schnürer, J., and J. Magnusson. 2005. Antifungal lactic acid bacteria as biopreservatives. Trends Food Sci. Technol. 16:70-78.

Sidira, M., A. Galanis, P. Ypsilantis, A. Karapetsas, Z. Progaki, C. Simopoulos, and Y. Kourkoutas. 2010. Effect of probiotic-fermented milk administration on gastrointestinal survival of Lactobacillus casei ATCC 393 and modulation of intestinal microbial flora. J. Mol. Microbiol. Biotechnol. 19:224-230.

Sidira, M., G. Saxami, D. Dimitrellou, V. Santarmaki, A. Galanis, and Y. Kourkoutas. 2013. Monitoring survival of Lactobacillus casei ATCC 393 in probiotic yogurts using an efficient molecular tool. J. Dairy Sci. 96:3369-3377.

Stanton, C., G. Gardiner, P. B. Lynch, J. K. Collins, G. Fitzgerald, and R. P. Ross. 1998. Probiotic cheese. Int. Dairy J. 8:491-496.

Viljoen, B. C. 2001. The interaction between yeasts and bacteria in dairy environments. Int. J. Food Microbiol. 69:37-44. 